\title{
Mother's Perception of Anemia and Compliance of Iron Tablet Consumption during Pregnancy
}

\author{
Martha Meti Kody ${ }^{1 *(\mathbb{D})}$, Melkisedek Landi ${ }^{1}$, Yosephina E. S. Gunawan ${ }^{1} \mathbb{D}$, Maria Christina Endang Sukartiningsih ${ }^{1}$ (D) \\ Norma Tiku Kambuno ${ }^{2}$ (D) \\ ${ }^{1}$ Department of Nursing, Poltekkes Kemenkes Kupang, Kupang, Indonesia; ${ }^{2}$ Department of Medical Laboratory Technology, \\ Poltekkes Kemenkes Kupang, Kupang, Indonesia
}

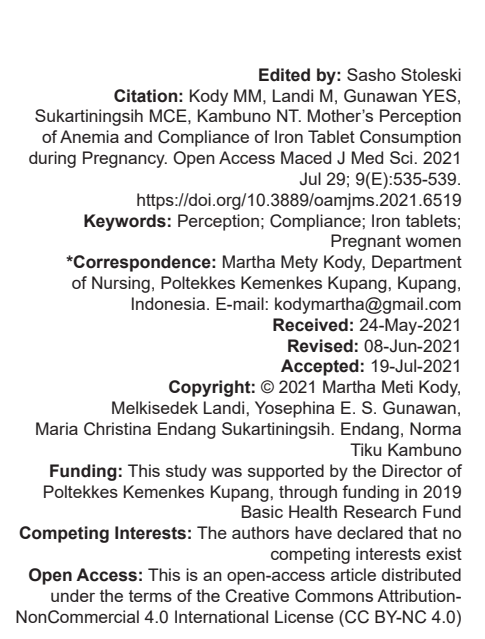

Abstract

BACKGROUND: Anemia cases are still the main problem found in pregnant women in East Nusa Tenggara Province, Indonesia, especially East Sumba Regency. Anemia is very common in pregnant women and iron (Fe) deficiency is the main cause. Indonesia has a policy to provide Fe supplements to pregnant women. Non-compliance of Fe tablets is one of the important challenge factors in fighting anemia.

AIM: The research objective was to determine the relationship between perceptions and compliance of pregnant women on consuming Fe tablets.

METHODS: This study involved 102 women, namely 34 pregnant women, 34 postpartum mothers, and 34 breastfeeding mothers. After obtaining approval from the research ethics commission, data were collected by personal interview. Data were analyzed using the Spearman correlation statistical test.

RESULTS: A good perception of $77.5 \%$, moderate $18.6 \%$, and less, $5.9 \%$. It was found that the compliance of taking Fe tablets was in the good category of $2.9 \%$, sufficient $27.5 \%$, and less $69.6 \%$. The results of the Spearman correlation test show a correlation coefficient of 0.164 and a significant 0.100 which means that there is a weak correlation and there is no relationship between perception and compliance of taking Fe tablets.

CONCLUSIONS: The perception of pregnant women about Fe is mostly good and the compliance of pregnant women's in taking Fe tablets is mostly sufficient. There was no relationship between perception and compliance of taking Fe tablets in pregnant women.

\section{Introduction}

Anemia is a condition in which the oxygencarrying capacity of red blood cells is insufficient to fill the body's physiological needs [1]. This can lead to various health complications in every age group including pregnant women, where it can lead to dangerous maternal and fetal outcomes [2]. It is estimated that $20 \%$ of direct maternal deaths are attributable to anemia through its complications and it is the associated cause of up to $50 \%$ of maternal deaths worldwide. The World Health Organization (WHO) defines anemia as a blood hemoglobin which concentration is $<11 \mathrm{gm} / \mathrm{dl}$ or a hematocrit $<37 \%$ in pregnant women. The WHO estimates that $58 \%$ of women in developing countries suffer from anemia [3].

According to Basic Health Research (Riskesdas) 2018, the prevalence of anemia in pregnant women in Indonesia is $48.9 \%$. The figure shows an increase when compared to Riskesdas in 2013, namely $37.1 \%$. knowing from the coverage of blood added tablets giving to pregnant women in 2018 , as many as
$38.1 \%$ of pregnant women who get iron ( $\mathrm{Fe}$ ) tablets of at least 90 items and $61.9 \%$ get Fe tablets $<90$ items [4]. The blood-added tablet distribution program is programmed for pregnant women and young women and the coverage of the number of TDD recipients is $18.92 \%$ and $61.88 \%$ in 2018 , respectively [5]. Report from the Directorate General of Public Health in 2018, the number of pregnant women at risk of chronic energy deficiency and underweight toddlers who receive additional food in East Nusa Tenggara $76.1 \%$ and $73 \%$. East Sumba Regency has 22 health centers including Puskesmas Waingapu with the number of pregnant women in 2018 was 5,642 people and the number of recipients of $\mathrm{Fe}$ tablets was 4,185 people $(74.2 \%)$. There were 48 cases of anemia in pregnant women at Puskesmas Waingapu in 2017 and decreased to 23 cases in 2018 [6].

Fe deficiency is considered the most common cause of anemia globally, accounted for more than half of anemia cases in pregnancy [7]. Fe, an essential nutrient, is needed for the synthesis of hemoglobin, Fe needs increase during pregnancy and is often not obtained through regular diet. This can be exacerbated 
by the loss of appetite during pregnancy [8]. Therefore, the most suitable method of intervention for $\mathrm{Fe}$ supplementation is the disposal of $\mathrm{Fe}$ together with folic acid in tablet form to pregnant women which aims to increase the hemoglobin concentration, so that anemia levels during pregnancy can be reduced as much as possible [1].

One of the government programs in Indonesia to prevent anemia in pregnancy is Fe supplementation which is distributed free of charge through Puskesmas and Posyandu by distributing Fe tablets that contain $60 \mathrm{mg}$ elemental Fe for at least 90 days during pregnancy [2]. Compliance describes the extent to which the patient is following medical advice properly. Some researchers have concluded that one of the main reasons for the failure of national Fe supplementation programs is women's "noncompliance". There are several factors including health system and patient factors that determine compliance, which is not studied extensively. There are no clear boundaries for non-compliance. Missing 2 or more doses in a row is usually considered non-compliance [9]. The role of health workers greatly affects mothers consuming Fe tablets, to implement a program of giving Fe tablets to pregnant women through counseling, recording and reporting activities, registering data on pregnant women who receive and take Fe tablets, visit houses.

Thus, compliance is very important for the management of anemia which in turn is influenced by several social and demographic factors, including perceptions and attitudes. This research was conducted at Puskesmas Waingapu, East Sumba Regency to assess perceptions and attitudes that influence the level of compliance among pregnant women consuming $\mathrm{Fe}$ tablets.

\section{Methods}

The type of research used in this research is quantitative observational cross-sectional analysis. The population in this study were all pregnant women in Puskesmas Waingapu in 2019 which include 136 people. The samples in this study were pregnant women, postpartum, and breastfeeding mothers who came for treatment and were recorded. The sampling technique used is Proportionale Stratified Random Sampling after being calculated using the Slovin formula. The number of samples was determined to be 102 samples divided by three types of sources. The 30 samples were divided into 34 samples were taken from pregnant women, 34 samples were taken from postpartum mothers, and 34 samples were taken from breastfeeding mothers. The research location was conducted at the Puskesmas Waingapu, East Sumba. This research was conducted in June 2019. The instrument used was the questionnaire based on the objective of the study to observe mother's perception of anemia and compliance of the consumption of bloodsupplemented tablets during pregnancy.

Data processing includes editing, decoding, scoring, and tabulating. Data were collected and grouped then processed quantitatively descriptive, presented in tabular and narrative form. The relationship between perception and compliance of taking blood-added tablets was analyzed using the Sperman correlation test with $\alpha=0.05$.

This research has received ethical permission from the Research Ethics Commission of the Health Polytechnic of the Ministry of Health in Kupang with the certificate number LB.02.02/1/0038/2019, all respondents were asked to be participated and signed a concern informant.

\section{Results}

Table 1 shows that the age of most respondents is in the age of 20-25 years and 26-30 years, respectively 32 people $(31.2 \%)$ of the total respondents. In terms of gestational age, most respondents were primigravida aged 20-25 years. It was found that there was still 1 mother who had a pregnancy of more than 4 with age over 40 years. Most of the respondents' education are senior high school, 31 people $(30.4 \%)$ and elementary school 25 people (24.5\%). Most of the respondents' occupations are housewives, namely, 60 people $(58.8 \%)$ and farmers 21 people (20.6\%). Seventy percent of respondents had received information about anemia, and most of them got information through electronic media 28 people (40\%), and through health education 22 people (31.4\%).

Table 2 show that most perception of the respondents was in the good category, 77 people $(75.5 \%), 19$ people $(18.6 \%)$ were in the sufficient category and there were still six people $5.9 \%$ in the poor category. The majority of respondents' compliance was in the less, namely, 71 people (69.6\%), 28 people $(27.5 \%)$ insufficient category, and only three respondents $(2.9 \%)$ in good category.

Table 3 shows the perceived correlation coefficient of compliance is 0.164 , meaning that the correlation coefficient is very weak. A significant value of $0.100,>0.05$, means that there is no relationship between perception and compliance of taking Fe tablets.

\section{Discussion}

$\mathrm{Fe}$ is a micronutrient, and essential minerals must be fulfilled from food intake. This mineral can 
Table 1: Distribution of respondents according to age and child pregnancy

\begin{tabular}{lll}
\hline Characteristics & $\mathrm{n}$ & $\%$ \\
\hline Mother's Age (Years) & 2 & 2 \\
$<20$ & 32 & 31.2 \\
$20-25$ & 32 & 31.2 \\
$26-30$ & 19 & 18.6 \\
$31-35$ & 14 & 13.7 \\
$36-40$ & 3 & 2.9 \\
$41-45$ & & \\
Pregnant with child number & 37 & 36.3 \\
1 & 26 & 25.5 \\
2 & 20 & 19.6 \\
3 & 13 & 12.7 \\
4 & 6 & 5.9 \\
$>4$ & & \\
Education & 10 & 9.8 \\
Did not go to school & 25 & 24.5 \\
Primary school & 21 & 20.6 \\
Junior high school & 31 & 30.4 \\
High school & 15 & 14.7 \\
Academy/College & & \\
Occupation & 60 & 58.8 \\
Housewife & 21 & 20.6 \\
Farmer & 10 & 9.8 \\
Civil servants & 5 & 4.9 \\
Private & 6 & 5.9 \\
Entrepreneur & & \\
Receiving information about anemia & 70 & 68.6 \\
Yes & 32 & 31.4 \\
No & & \\
Resources & & \\
Electronic media (television, radio) & 28 & 40 \\
Print media (newspapers, books, tabloids, magazines) Health & 20 & 28.6 \\
Education & 22 & 31.4 \\
Total & 102 & 100 \\
\hline
\end{tabular}

be found easily in animal-based and plant-based foods. The food known as a source of Fe is red meat, liver, spinach/green vegetables, nuts, and seafood. However, $\mathrm{Fe}$ is an unstable mineral and can easily react with anti-nutritional substances, such as tannins, polyphenols, caffeine, or phytates abundant in coffee, tea, chocolate, and nuts [10], [11]. Low Fe intake will continue to cause anemia, a state of lack of red blood cells, or malfunctioning red blood cells in the body. It will reduced oxygen flow to the organs of the body.

Table 2: The results of measurement level of perception and compliance

\begin{tabular}{llllll}
\hline Variable & Perception & & & Compliance & \\
\cline { 2 - 3 } & $\mathrm{n}$ & 7 & & & \\
\hline Good & 77 & 75.5 & & 3 & 2.9 \\
Sufficient & 19 & 18.6 & & 28 & 27.5 \\
Less & 6 & 5.9 & & 71 & 69.6 \\
\hline
\end{tabular}

Anemia can be caused by nutrient deficiency, which is the most common anemia in society. This type of anemia is the deficiency of particular nutrients, including $\mathrm{Fe}$, vitamin B9 (folate), and vitamin B12. Then, there are anemias caused by genetic factors due to abnormalities in the body's metabolism, including aplastic anemia, sickle cell anemia, thalassemia, and others. The genetic causes may difficult to prevent. However, the nutrient deficiency anemias can be overcome by improving the intake of respective nutrients.

Table 3: Distribution of test results Spearman's rho correlation perception with compliance with Fe tablets

\begin{tabular}{lll}
\hline Spearman's rho & Perception & Obedience \\
\hline Perception & 1.000 & 0.164 \\
$\quad$ Correlation Coefficient & & 0.100 \\
Sig & & \\
Compliance & 0.164 & 1.000 \\
$\quad$ Correlation Coefficient & 0.100 & \\
Sig & & \\
\hline
\end{tabular}

Anemia is at risk for serious health complications. It may affect the body's cellular health. At low levels, sufferers will feel a decrease in fitness, cause fatigue, and then cause complications for the heart, lungs, and even the reproductive system [12], [13], [14]. It would be more dangerous if anemia occurs in pregnant women. It will affect the health of both the mother and the baby, which will affect the safety of the mother and baby during childbirth. Various attempts have been made to improve the anemia status of mothers and children. The government and the health office are conducting a campaign to control anemia among young women who are prospective mothers regarding the importance of the nutrient $\mathrm{Fe}$. In addition, the government also runs a food fortification and an Fe supplementation program for pregnant women.

Fe supplementation is still a priority in efforts to eradicate anemia in pregnant women. In general, the need for $\mathrm{Fe}$, which increases quite sharply during pregnancy, cannot be fulfilled from daily food, especially in developing countries. Beberapa penelitian memperlihatkan bahwa suplementasi harian fe pada ibu hamil memperlihatkan bahwa efektif dalam menurunkan anemia, peningkatan jumlah hemoglobin, penurunan resiko bayi dengan berat lahir rendah, serta penurunan resiko kelahiran premature [15], [16]

We found that the low compliance of pregnant women in consuming $\mathrm{Fe}$ tablets is one of the health problems that must receive attention from the East Sumba district government. Anemia has a serious impact on pregnant women and the fetus to be born. Pregnant women with anemia increase the risk of abortion, preterm labor and postpartum haemorrhage [17], [18]. As for the fetus, it can cause growth problems in children at the beginning of their growth period and low birth weight [19]. If it is necessary, we recommend empowering husbands and other family members as supervisors for drinking Fe tablets for pregnant women [20]. Concern in paying attention and monitoring the consumption of Fe tablets every day increases the compliance of pregnant women in consuming Fe tablets.

The role of the family, especially the husband as a reinforcing factor, plays an important role in increasing compliance in consuming $\mathrm{Fe}$ tablets. Concern in paying attention and monitoring the consumption of Fe tablets every day increases the compliance of pregnant women in consuming Fe tablets [9].

We recommend a family approach through counseling, door-to-door visits by health workers. The participation of health personnel including doctors, midwives, and nurses who handle pregnant women is very important to influence pregnant women in the aspect of compliance with consuming Fe tablets. In a study conducted by Ghasemi-Rad et al., it was found that most pregnant women received information 
about anemia and Fe tablets from medical personnel from other sources of information such as the media. Increasing outreach activities or providing health counseling during antenatal visits is expected to increase the knowledge of pregnant women so that compliance can also be improved [21]

\section{Conclusions}

The most perception of pregnant women about Fe was good and the most compliance of taking medication for the pregnant women was sufficient at Puskesmas Waingapu East Sumba Regency. There is no relationship between perception and compliance of taking $\mathrm{Fe}$ tablets in pregnant women. Family empowerment is needed in monitoring Fe tablets taking and increasing the supervisory role of health workers at the Puskesmas.

\section{Acknowledgment}

We would like to thank the Director of Poltekkes Kemenkes Kupang, Dr. RH Kristina, SKM. M.Kes for his support through funding in 2019 Basic Health Research Fund. Thanks to the Head of the Waingapu Nursing Study Program for his support during the research implementation. In particular, the head of the East Sumba District Health Office, the Head of Puskesmas Waingapu, who had given permission to carry out the research. A big gratitude to all respondents who agreed to be interviewed and had provided the information we needed.

\section{References}

1. Patra S. Motherhood in childhood: Addressing reproductive health hazards among adolescent married women in India. Reprod Health. 2016;13(1):52. https://doi.org/10.1186/ s12978-016-0171-7

PMid:27142211

2. Septiani W. Pelaksanaan program pemberian tablet zat besi (Fe) pada ibu hamil. J Midwifery Sci. 2017;1(2):86-92.

3. Nguyen PH, Kachwaha S, Avula R, Young M, Tran LM, Ghosh S, et al. Maternal nutrition practices in Uttar Pradesh, India: Role of key influential demand and supply factors. Matern Child Nutr. 2019;15(4):1-15. https://doi.org/10.1111/mcn.12839

4. Tim Riskesdas 2018. Laporan Riskesdas 2018. Vol. 1. Tim Riskesdas; 2019. p. 1-550.

5. NTT DP. Profil Kesehatan Provinsi Nusa Tenggara Timur. NTT DP; 2018. p. 1-146.
6. Dinkes Kota Kupang. Profil Kesehatan Kota Kupang. Dinkes Kota Kupang; 2018. p. 19-21.

7. Smittenaar $\mathrm{P}$, Ramesh BM, Jain M, Blanchard J, Kemp H, Engl $\mathrm{E}$, et al. Bringing greater precision to interactions between community health workers and households to improve maternal and newborn health outcomes in india. Glob Health Sci Pract. 2020;8(3):358-71. https://doi.org/10.9745/ghsp-d-20-00027 PMid:33008853

8. Purbowati N. The effect of counseling using flipcharts and leaflets on the compliance of pregnant women in consuming iron tablets. Tunas Riset Kesehatan. 2016;6(3):1430147. https://doi. org/10.37413/jmakia.v4i1.28

9. Ramawati $D$, Sejati W. Factors that affect the compliance of pregnant women in consuming iron tablets in Sokaraja Tengah Village, Sokaraja District, Banyumas Regency. Soedirman J Nurs. 2008;3(3):114-24. https://doi.org/10.37402/jurbidhip.vol4. iss 2.4

10. Omar NF, Hassan SA, Yusoff UK, Abdullah NA, Wahab PE, Sinniah UR. Phenolics, flavonoids, antioxidant activity and cyanogenic glycosides of organic and mineral-base fertilized cassava tubers. Molecules. 2012;17(3):2378-87. https://doi. org/10.3390/molecules 17032378

PMid:22370524

11. Omoruyi FO, Dilworth L, Asemota HN. Anti-nutritional factors, zinc, iron and calcium in some caribbean tuber crops and the effect of boiling or roasting. Nutr Food Sci. 2007;37(1):8-15. https://doi.org/10.1108/00346650710726904

12. Nangaku M, Eckardt KU. Pathogenesis of renal anemia Semin Nephrol. 2006;26(4):261-8. https://doi.org/10.1016/j. semnephrol.2006.06.001 PMid:16949463

13. Haas JD, Brownlie $\mathrm{T} 4^{\text {th }}$. Iron deficiency and reduced work capacity: A critical review of the research to determine a causal relationship. J Nutr. 2001;131(2):676S-90. https://doi. org/10.1093/jn/131.2.676s PMid: 11160598

14. Tang YD, Katz SD. Anemia in chronic heart failure. Circulation. 2006;113(20):2454-61 PMid:16717164

15. Peña-Rosas JP, De-Regil LM, Garcia-Casal MN, Dowswell T. Daily oral iron supplementation during pregnancy. Cochrane Database Syst Rev. 2015;7:CD004736. https://doi. org/10.1002/14651858.cd004736.pub5 PMid:26198451

16. Beard JL. Effectiveness and strategies of iron supplementation during pregnancy. Am J Clin Nutr. 2000;71(5):1288S-94. https:// doi.org/10.1093/ajcn/71.5.1288s

PMid:10799404

17. Mithra $\mathrm{P}$, Unnikrishnan $\mathrm{B}$, Rekha $\mathrm{T}$, Nithin $\mathrm{K}$, Mohan $\mathrm{K}$, Kulkarni V, et al. Compliance with iron-folic acid (IFA) therapy among pregnant women in an urban area of South India. Afr Health Sci. 2014;14(1):6-11. https://doi.org/10.4314/ahs. v13i4.3 PMid:24940307

18. Nguyen PH, Sanghvi T, Kim SS, Tran LM, Afsana K, Mahmud Z, et al. Factors influencing maternal nutrition practices in a large scale maternal, newborn and child health program in Bangladesh. PLoS One. 2017;12(7):e0179873. https://doi. org/10.1371/journal.pone.0179873 PMid:28692689

19. Zavaleta N, Caulfield LE, Figueroa A, Chen P. Patterns of compliance with prenatal iron supplementation among Peruvian women. Matern Child Nutr. 2014;10(2):198-205. https://doi. org/10.1111/j.1740-8709.2012.00407.x

PMid:22590991 
20. Aditianti A, Permanasari $Y$, Julianti ED. Assistance in taking blood-added tablets can improve adherence to TTD consumption in anemic pregnant women. J Nutr Food Res. 2015;38(1):71-8. https://doi.org/10.22435/pgm.v38i1.4424.71-78
21. Ghasemi-Rad M, Yekta Z, Pourali R, Mladkova N, Boromand F. Role of iron supplementation in promoting maternal and fetal outcome. Ther Clin Risk Manage. 2011;2011:421. https://doi. org/10.2147/tcrm.s16892 